\title{
Pelatihan Kader Kelas Ibu Hamil "Persiapan 1000 Hari Pertama Kehidupan" di Desa Leminggir Kecamatan Mojosari Kabupaten Mojokerto
}

\author{
Heni Purwati ${ }^{1}$, Etik Khusniyati ${ }^{2}$, Elies Meilinawati SB ${ }^{3}$, Faisal Ibnu ${ }^{4}$ \\ ${ }^{1}$ Kebidanan (D3), STIKes Bina Sehat PPNI, Mojokerto, Indonesia \\ ${ }^{2,3}$ Kebidanan (S1), STIKes Bina Sehat PPNI, Mojokerto, Indonesia \\ ${ }^{4}$ Keperawatan (S1), STIKes Bina Sehat PPNI Mojokerto, Indonesia \\ e-mail: 'hn.purwati@gmail.com, ${ }^{2}$ etik.khusniyati@gmail.com, ${ }^{3}$ eliesmsb@gmail.com, \\ ${ }^{4}$ masfaizppni@gmail.com
}

\begin{abstract}
ABSTRAK Masa 1000 hari pertama kehidupan (HPK) merupakan bagian terpenting dalam kehidupan manusia. Pada masa ini orang tua memiliki peran penting untuk memberikan perawatan dan pengasuhan yang berkualitas sesuai dengan tahap perkembangan anak, karena pada masa ini proses tumbuh kembang anak dimulai, gizi untuk kelompok ini harus dipandang sebagai bagian investasi untuk menanggulangi kemiskinan melalui peningkatan pendidikan dan kesehatan. Adanya informasi baru akan memberikan landasan kognitif baru bagi terbentuknya sikap seseorang. Audiovisual memberikan kontribusi yang sangat besar dalam perubahan perilaku masyarakat terutama dalam aspek informasi dan persuasi. Kegiatan pengabdian masyarakat ini dilakukan dengan dengan tujuan meningkatkan pengetahuan kader tentang 1000 Hari Pertama Kehidupan dengan cara memberikan health education menggunakan media audio visual, kader diberikan kuesioner pre test untuk mengukur pengetahuan kader kemudian dilakukan health education setelah itu diberikan post test. Didapatkan hasil skor pengetahuan sebelum perlakuan rata-rata 81,0909 dan setelah perlakuan meningkat menjadi 85,2727 dimana skor tersebut terdapat selisih 4,1818 atau terjadi peningkatan sebesar $45,4 \%$, skor $\rho$-value $=0,016$ ( $\rho$-value $<0,05)$ yang berarti terdapat perbedaan skor yang signifikan antara sebelum dan sesudah dilakukan health education dengan menggunakan media audio visual (video) pada kader ibu hamil atau terdapat peningkatan yang signifikan pengetahuan tentang persiapan 1000 Hari Pertama Kehidupan setelah dilakukan health education dengan menggunakan media audio visual. Pengabdian masyarakat dengan menggunakan audio visual ini terbukti dapat meningkatkan pengetahuan kader tentang 1000 Hari Pertama kehidupan, dengan adanya peningkatan pengetahuan kader tentang 1000 Hari Pertama Kehidupan, kader dapat membantu ibu hamil untuk mempersiapkan 1000 Hari Pertama Kehidupan dengan tepat.
\end{abstract}

KATA KUNCI Pengetahuan; 1000 hari pertama kehidupan.

ABSTRACT The first 1000 days of life (HPK) are the most important part of human life. At this time parents have an important role to provide quality care and care in accordance with the stage of child development, because at this time the child's growth and development process begins. Nutrition for this group must be seen as part of an investment to reduce poverty through improved education and health. The existence of new information about something will provide a new cognitive basis for the formation of a person's attitude. Audiovisual makes a huge contribution in changing people's behavior, especially in the aspects of information and persuasion. This community service activity is carried out by 
giving cadre health education given a pre-test questionnaire to measure the cadre's knowledge then health education is conducted after it is given a post test. Knowledge score before the treatment was obtained an average of 81.0909 and after treatment increased to 85.2727 where the score contained a difference of 4.1818 or an increase of $45.4 \%$, a score of $\rho$-value $=0.016$ ( $\rho$-value $<0,05)$ which means there is a significant difference in scores between before and after health education using audio-visual media (video) for cadres of pregnant women or there is a significant increase in knowledge about the preparation of the First 1000 Days of Life after health education using audio-visual media. Community service using audio visuals is proven to be able to increase cadres' knowledge of the First 1000 Days of life, by increasing cadres' knowledge, cadres can help pregnant women to prepare for the First 1000 Days of Life properly.

KEYWORDS knowledge; the first 1000 days of life

\section{Pendahuluan}

Masa 1000 hari pertama kehidupan (HPK) merupakan bagian terpenting dalam kehidupan manusia. Pada masa ini orang tua memiliki peran penting untuk memberikan perawatan dan pengasuhan yang berkualitas sesuai dengan tahap perkembanan anak, karena pada masa ini proses tumbuh kembang anak dimulai. Seribu hari pertama kehidupan dimulai sejak pembuahan sampai dengan 2 tahun pertama kehidupan anak. Pada periode ini otak bayi sedang berkembang pesat, sehingga bila terjadi masalah gizi akan berpengaruh juga perkembangan otak dan tubuh bayi. Status gizi dan kesehatan ibu dan anak sebagai penentu kualitas sumber daya manusia, hal ini dibuktikan dengan adanya status gizi dan kesehatan ibu pada masa pra hamil, saat kehamilannya dan saat menyusui merupakan periode yang sangat kritis. Perkembangan kognitif dan fisik seorang anak dipengaruhi oleh 1000 hari pertama kehidupan, dari konsepsi hingga ulang tahun kedua. Hal ini, pada gilirannya, dipengaruhi oleh faktor biologis, seperti nutrisi ibu selama kehamilan, usia kehamilan, berat lahir, lama menyusui, malnutrisi masa kanak-kanak, infeksi masa kanak-kanak dan faktor psikososial, seperti status ekonomi, pendidikan orang tua dan paparan lingkungan. Seringkali ini adalah domain yang saling bergantung dan anak-anak yang terpapar pada banyak faktor adalah yang paling rentan. Akumulasi risiko dari waktu ke waktu membahayakan perkembangan anak secara keseluruhan.[1] Apabila tidak diperbaiki, terjadinya IUGR dan BBLR akan terus berlangsung di generasi selanjutnya, sehingga terjadi masalah anak pendek intergenerasi. Siklus tersebut akan terus terjadi apabila tidak ada perbaikan gizi dan pelayanan kesehatan yang memadai pada masa-masa tersebut[2]. Kelompok 1000 HPK penting untuk diperhatikan untuk mengurangi jumlah anak pendek di generasi yang akan datang dan seterusnya. Dengan itu, akan ditingkatkan kualitas manusia dari aspek kesehatan, pendidikan dan produktivitasnya yang akhirnya bermuara pada peningkatan kesejahteraan masyarakat[3]. Para ahli ekonomi dunia perbaikan gizi pada 1000 HPK adalah suatu investasi pembangunan yang "cost effective"[4].

Suatu yang menggembirakan bahwa berbagai masalah tersebut di atas bukan disebabkan terutama oleh faktor genetik yang tidak dapat diperbaiki seperti diduga oleh sebagian masyarakat, melainkan oleh karena faktor lingkungan hidup yang dapat diperbaiki dengan fokus pada masa 1000 HPK. Investasi gizi untuk kelompok ini harus dipandang sebagai bagian investasi untuk menanggulangi kemiskinan melalui peningkatan pendidikan dan kesehatan[5]. 
Adanya informasi baru mengenai sesuatu hal akan memberikan landasan kognitif baru bagi terbentuknya sikap seseorang. Pesan-pesan sugestif yang dibawa oleh informasi apabila cukup kuat akan memberi dasar afektif dalam menilai sesuatu sehingga membentuk arah sikap tertentu[6]. Dalam UndangUndang Republik Indonesia nomor 23 tahun 1992 tentang kesehatan disebutkan penyuluhan kesehatan masyarakat diselenggarakan guna meningkatkan pengetahuan, kesadaran, kemauan, dan kemampuan masyarakat untuk hidup sehat, dan aktif berperan serta dalam upaya kesehatan. Menurut Notoatmodjo, pemberian penyuluhan kesehatan dalam upaya meningkatkan pengetahuan dapat dilakukan dengan menggunakan alat bantu promosi kesehatan berupa alat bantu lihat (visual aids), alat bantu dengar (audio aids) dan alat bantu lihat dengar (Audio Visual Aids). Audiovisual merupakan salah satu alat bantu penyuluhan. Media audiovisual lebih efektif dalam menerima pembelajaran karena dapat memberikan pengalaman nyata lebih dari yang disampaikan media audio maupun visual. Audiovisual memberikan kontribusi yang sangat besar dalam perubahan perilaku masyarakat, terutama dalam aspek informasi dan persuasi. Alat bantu ini memberikan stimulus pada pendengaran dan penglihatan, sehingga hasil yang diperolah lebih maksimal.[7] Pengabdian masyarakat ini bertujuan untuk meningkatkan pengetahuan tentang 1000 Hari Pertama Kehidupan pada kader Kelas Ibu Hamil di Desa Leminggir Kecamatan Mojosari Kabupaten Mojokerto, sehingga Kader Kelas Ibu Hamil diharapkan dapat membantu ibu hamil dalam menyiapkan 1000 Hari Pertama Kehidupan dengan tepat.

\section{Metode}

Pelaksanaan Pengabdian Masyarakat tentang pelatihan kader persiapan 1000 Hari Pertama Kehidupan di Desa Leminggir Kec Mojosari Kab Mojokerto bertujuan untuk meningkatkan pengetahuan kader tentang 1000 Hari Pertama Kehidupan, pengabdian masyarakat ini dilakukan dengan menggunakan metode pre test pengetahuan kader tentang Persiapan 1000 Hari Pertama Kehidupan, melakukan pemutaran video serta evaluasi melalui post test. Pengabdian masyarakat ini dilaksanakan pada tanggal 23 Nopember 2019. Sasaran pada kegiatan pengabdian masyarakat ini adalah Kelompok kader kelas ibu hamil Desa Leminggir sejumlah 11 orang. Prosedur pelaksanaan Pengabdian Masyarakat ini dilakukan dengan prosedur persiapan dengan menyiapkan semua peralatan yang dibutuhkan untuk melaksanan kegiatan ini, studi literatur dan melakukan koordinasi dengan instansi terkait (IT, pakar bidang kesehatan) untuk melakukan kegiatan pembuatan video edukasi persiapan 1000 hari pertama kehidupan serta sosialisasinya. Prosedur berikutnya adalah kunjungan ke lokasi untuk menentukan tempat (lokasi) sosialisasi pengembangan video edukasi persiapan 1000 hari pertama kehidupan. Lokasi program ini di wilayah Desa Leminggir Mojokerto. Langkah selanjutnya adalah melakukan pendekatan dengan menggunakan kearifan budaya lokal masyarakat mitra. Untuk melakukan hal ini, tim pelaksana program mengikutsertakan tenaga kesehatan yang ada di masyarakat mitra. Adapun langkah terakhir dari kegiatan ini adalah menggali pemahaman kader ibu hamil Desa Leminggir tentang persiapan 1000 Hari Pertama Kehidupan dengan penyebaran angket.

\section{Hasil dan Pembahasan}

Telah dilakukan koordinasi dengan bidan pengelola kelas hamil, kemudian dilakukan health education dengan menggunakan media audio visual (multimedia). Dalam kegiatan ini dilakukan pengukuran pengetahuan kader kelas ibu hamil sebelum diberikan health education dan setelah diberikan health 
education, pengukuran ini bertujuan untuk mengkaji adakah peningkatan pengetahuan setelah diberikan health education.

3.1 Penyajian table

Hasil dari kegiatan pengabdian masyarakat ini didapatkan data sebagai berikut :

Tabel 1. Distribusi Frekuensi berdasarkan Usia Kader

\begin{tabular}{cccc}
\hline No & Usia (tahun) & Frekuensi & Prosentase $(\%)$ \\
\hline 1 & $<20$ tahun & 0 & $0 \%$ \\
2 & $20-30$ tahun & 0 & $0 \%$ \\
3 & $31-40$ tahun & 6 & $54,5 \%$ \\
4 & $>40$ tahun & 5 & $45,5 \%$ \\
\hline \multicolumn{2}{r}{ Total } & $\mathbf{1 1}$ & $\mathbf{1 0 0 \%}$
\end{tabular}

Berdasarkan tabel 1 usia kader peserta kegiatan adalah separuh $(54,5 \%)$ dari peserta berusia antara $31-40$ tahun.

Tabel 2. Distribusi Frekuensi berdasarkan Pendidikan Kader

\begin{tabular}{clcc}
\hline No & Pendidikan & Frekuensi & $\begin{array}{c}\text { Prosentase } \\
(\mathbf{\%})\end{array}$ \\
\hline 1 & SD/MI & 0 & $0 \%$ \\
2 & SLTP/MTs & 2 & $18,18 \%$ \\
3 & SLTA/SMK/MA & 7 & $63,64 \%$ \\
4 & Perguruan Tinggi & 2 & $18,18 \%$ \\
\hline & Total & $\mathbf{1 1}$ & $\mathbf{1 0 0 \%}$ \\
\hline
\end{tabular}

Berdasarkan tabel 2 dapat diketahui pendidikan kader peserta kegiatan pengabdian masyarakat adalah setingkat SLTA $(63,64 \%)$

Tabel 3. Pengetahuan kader sebelum dan setelah dilakukan Health Education

\begin{tabular}{ccc}
\hline No Responden & Skor Sebelum & Skor Sesudah \\
\hline 1 & 86 & 86 \\
2 & 80 & 91 \\
3 & 86 & 89 \\
4 & 74 & 83 \\
5 & 80 & 83 \\
6 & 80 & 86 \\
7 & 83 & 83 \\
8 & 83 & 83 \\
9 & 74 & 83 \\
10 & 75 & 77 \\
11 & 91 & 94 \\
\hline
\end{tabular}

Tabel 4 Uji Statistik Perbedaan Pengetahuan kader sebelum dan setelah dilakukan Health Education

\begin{tabular}{cccccc}
\hline Parameter & n & Mean & SD & Selisih & $\boldsymbol{\rho}$ - value \\
\cline { 1 - 4 } Sebelum & 11 & 81,0909 & 5,430 & & 4,1818 \\
\cline { 1 - 2 } Sesudah & 11 & 85,2727 & 4,670 & & 0,016 \\
\hline
\end{tabular}


Setelah dilakukan uji statistik dengan menggunakan uji Paired sample t-Test, maka diketahui bahwa skor pengetahuan sebelum perlakuan rata-rata 81,0909 dan setelah perlakuan meningkat menjadi 85,2727

\subsection{Penyajian grafik}

Bila digambarkan dalam grafik, dapat terlihat bahwa pengetahuan kader setelah dilakukan pengetahuan cenderung lebih tinggi dibandingkan pengetahuan sebelum pelatihan, pengetahuan kader setelah pelatihan

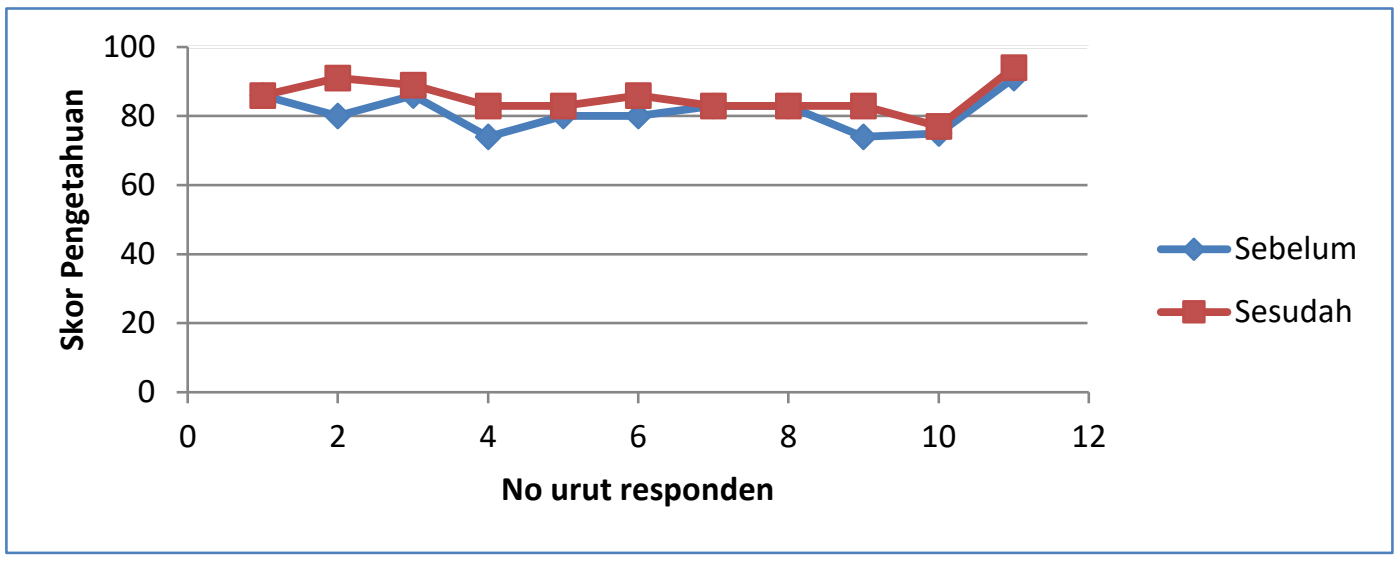

Gambar 1. Grafik pengetahuan kader

Hasil penelitian menunjukan nilai rerata skor pengetahuan sebelum pelatihan berada pada kategori baik yaitu 81,0909. Hasil analisis nilai rerata skor pengetahuan setelah pelatihan meningkat menjadi 85,2727. Pengetahuan yang dimiliki responden sebelum pelatihan sudah baik, melihat karakteristik umur dan pendidikan responden memungkinkan responden mempunyai pengetahuan yang baik. Pengalaman responden mempunyai anak merupakan dasar membentuk pengetahuan yang baik. Pengalaman adalah kejadian yang pernah dialami, dijalani dan dirasai oleh seseorang, baik yang sudah lama atau baru saja terjadi. Pengalaman merupakan salah satu faktor yang membentuk pengetahuan seseorang, sehingga banyak orang yang mengatakan pengalaman merupakan guru terbaik dalam hidup. Selain hal tersebut, paparan media juga menjadi salah satu faktor yang dapat memengaruhi pengetahuan seseorang, mengingat waktu sekarang ini banyak iklan yang mempromosikan tentang 1000 hari pertama kehidupan. Nilai rerata skor pengetahuan mengalami peningkatan skor yang cukup bermakna antara sebelum dan sesudah pelatihan. dimana skor tersebut terdapat selisih 4,1818 atau terjadi peningkatan sebesar $45,4 \%$, skor $\rho$-value $=$ $0,016$ ( $\rho$-value $<0,05)$ yang berarti terdapat perbedaan skor yang signifikan antara sebelum dan sesudah dilakukan health education dengan menggunakan media audio visual (video) pada kader ibu hamil atau terdapat peningkatan yang signifikan pengetahuan tentang persiapan 1000 Hari Pertama Kehidupan setelah dilakukan health education dengan menggunakan media audio visual (multimedia).

Sebagaimana kita ketahui bahwa tujuan pelatihan adalah untuk meningkatkan pengetahuan dan keterampilan tertentu agar peserta semakin terampil dan mampu melaksanakan tanggung jawabnya dengan baik sesuai dengan standar melalui serangkaian prosedur yang sistematis yang dilakukan oleh seorang ahli yang bertujuan untuk meningkatkan keterampilan dan pengetahuan kepada peserta[8][9]. Hal ini sudah sesuai dengan hasil penelitian dimana terjadi peningkatan pengetahuan antara sebelum dan sesudah perlakuan. Tujuan pelatihan 
dapat lebih optimal dengan pemanfaatan multimedia. Menurut penelitan yang dilakukan oleh Budianto, penggunaan video pembelajaran dapat membantu peserta memahami suatu konsep, secara lebih menyeluruh.[10] Tujuan penggunaan multimedia dalam pelatihan adalah untuk meningkatkan efisiensi dan efektivitas pelatihan, baik waktu, dana, fasilitas, maupun tenaga guna mencapai tujuan secara optimal serta mempersiapkan pembelajaran individual, sehingga responden mempunyai waktu luang untuk lebih mendalami materi pelatihan[11][12]. Menurut penelitian Sanjaya, kelompok belajar dengan menggunakan multimedia interaktif yang dikembangkan memiliki tingkat kemajuan belajar lebih tinggi dibandingkan dengan kelompok belajar dengan menggunakan modul textbook[13]. Sesuai dengan penelitian yang telah dilakukan oleh Juriah, dengan menggunakan multimedia peserta didik dapat menerima pembelajaran dalam bentuk yang lebih nyata dan lebih konkrit, materi yang telah divisualisasikan dengan menggunakan multimedia mampu menarik perhatian peserta didik dalam belajar, sehingga mereka menjadi lebih antusias dalam mengikuti proses pembelajaran, serta dapat meningkatkan motivasi mereka dalam belajar.[14][15][16]

Berdasarkan hasil penelitian tersebut, maka penggunaan multimedia sebagai sarana dalam pelatihan kader adalah metode yang tepat, kader dapat lebih mudah dan memiliki kemampuan belajar lebih tinggi dibandingkan hanya dengan menggunakan leaflet atau buku. Peningkatan pengetahuan responden diduga karena responden mempunyai kesempatan lebih luang untuk mempelajari materi 1000 hari pertama kehidupan, dengan alokasi waktu antara pre-test dengan post test lebih kurang 1-3 minggu.

\section{Kesimpulan}

Kegiatan pengabdian masyarakat yang telah dilakukan berupa Pelatihan Kader Kelas Ibu Hamil tentang Persiapan 1000 Hari Pertama Kehidupan dengan menggunakan media audio visual (multimedia) dapat meningkatkan pengetahuan kader kelas ibu hamil. Penggunaan multimedia (audio visual aids) merupakan pilihan metode yang tepat dalam meningkatkan pengetahuan kader kelas ibu hamil dibandingkan metode konvensional yang hanya dengan menggunakan textbook atau leaflet.

\section{Ucapan Terima kasih}

Puji syukur kehadirat Allah SWT yang telah melimpahkan rahmatNya sehingga penulis dapat menyelesaikan Kegiatan Pengabdian Masyarakat tentang Pelatihan Kader Kelas Ibu Hamil Persiapan 1000 Hari Pertama Kehidupan. Dalam kesempatan ini penulis menyampaikan ucapan terima kasih yang tidak terhingga kepada :

1. Dr. Muhammad Sajidin, SKp., M.Kes selaku Ketua STIKes Bina Sehat PPNI yang telah memberikan kesempatan kepada penulis untuk melakukan Pengabdian masyarakat.

2. Lasiyati Yuswo Yani, SST., M.Keb Selaku Ketua LPPM STIKes Bina Sehat PPNI Mojokerto.

3. Hj. Titik Rahmawati, SST, selaku Bidan di Desa Leminggir Kecamatan Mojosari Kabupaten Mojokerto yang telah membantu dengan penuh kesabaran dalam kegiatan Pengabdian masyarakat.

4. Kader ibu hamil di Desa Leminggir Kecamatan Mojosari Kabupaten Mojokerto sebagai responden yang telah banyak membantu dalam proses pengabdian masyarakat. 
5. Semua pihak yang tidak mungkin disebutkan satu persatu yang memberikan dukungan moral maupun material kepada penulis.

\section{Daftar Pustaka}

[1] D. Kattula et al., "The first 1000 days of life: prenatal and postnatal risk factors for morbidity and growth in a birth cohort in southern India," BMJ Open, vol. 4, no. 7, 2014.

[2] C. W. Kuzawa et al., "Birth weight, postnatal weight gain, and adult body composition in five low and middle income countries," Am. J. Hum. Biol., vol. 24, no. 1, pp. 5-13, 2012.

[3] D. J. P. Barker, "Developmental origins of chronic disease," Public Health, vol. 126, no. 3, pp. 185-189, 2012.

[4] R. Birner, "Bioeconomy concepts," in Bioeconomy, Springer, Cham, 2018, pp. 17-38.

[5] K. Kawai, D. Spiegelman, A. H. Shankar, and W. W. Fawzi, "Maternal multiple micronutrient supplementation and pregnancy outcomes in developing countries: meta-analysis and meta-regression," Bull. World Health Organ., vol. 89, pp. 402-411, 2011.

[6] D. W. Sjuchro, F. Hariyanto, E. Yusup, and Z. Abidin, "Program Siaran Radio Pemerintah Sturada 104.00 FM dalam Memenuhi Kebutuhan akan Informasi Mahasiswa Ilmu Komunikasi Universitas Singaperbangsa Karawang," J. Polit. Indones., vol. 3, no. 1, p. 41, 2018.

[7] S. Notoatmojo, Pendidikan dan Perilaku Kesehatan. Jakarta: Rineka Cipta, 2003.

[8] E. Yulianti, "Pengaruh Pelatihan Terhadap Kinerja Karyawan Grand Fatma Hotel di Tenggarong Kutai Kartanegara," E-Jurnal Adm. Bisnis, vol. 3, no. 4, pp. 900-910, 2015.

[9] S. Huda, Strategi Peningkatan Kinerja Melalui Pelatihan Efektif. Yayasan Warkat Utama, 2018.

[10] A. Budianto, S. Syahmani, and M. Istyadji, "Komparasi Hasil Belajar Antara Strategi Predict-Discuss-Explain-Observe-Discuss-Explain (PDEODE) Berbasis Laboratorium Dan Berbasis Multimedia Pada Pembelajaran Kelarutan Dan Hasil Kali Kelarutan," Quantum, J. Inov. Pendidik. Sains, vol. 6, no. 1, pp. 1-7, 2015.

[11] S. Z. Mohid, R. Ramli, K. A. Rahman, and N. N. Shahabudin, "Teknologi Multimedia dalam Pendidikan Abad," Int. Res. Manag. Innov. Conf., no. August, pp. 1-9, 2018.

[12] J. Simarmata, "Teknologi Multimedia Dalam Pendidikan," Pengemb. Media Pembelajaran Berbas. Teknol. Pendidik., p. 7, 2018.

[13] R. Sanjaya, "Multimedia Interaktif Pelatihan Service Excellent Menggunakan Pendekatan Story Based Learning," J. Inform., vol. 3, no. 1, 2016.

[14] J. Juriah, "Penggunaan Multimedia Dalam Meningkatkan Motivasi Belajar Siswa Pada Mata Pelajaran Aqidah Kelas X TKJ SMK Muhammadiyah 3 Surakarta Tahun Pelajaran 2013/2014.” Universitas Muhammadiyah Surakarta, 2014.

[15] I. Kholil, "Pengaruh Model Pembelajaran Berbasis Multimedia Interaktif Pada Siswa Madrasah Diniyah Al-Ahya," Simnasiptek 2017, vol. 1, no. 1, pp. 31-34, 2017.

[16] G. Majidahayu, "Implementasi Pembelajaran Matematika Melalui Model Discovery Learning Berbasis Multimedia Ditinjau Dari Kreativitas Matematika Siswa Kelas VIII SMP Negeri 1 Grobogan Tahun Ajaran 2014/2015." Universitas Muhammadiyah Surakarta, 2015. 